\title{
Eastern Exoticism: Thackeray as Tourist and Anti-Tourist
}

\section{Doğu Egzotizmi: Bir Turist ve Anti-Turist Olarak Thackeray}

\author{
Valerie Kennedy* (i)
}

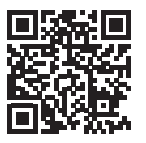

"Assistant Professor Doctor, Bilkent University, Faculty of Humanities and Letters Department of English Language and Literature, Ankara, Turkey

\section{ORCID:V.K. 0000-0002-7669-215X}

Corresponding author/Sorumlu yazar: Valerie Kennedy,

Bilkent University, Faculty of Humanities and Letters Department of English Language and Literature, Ankara, Turkey

E-mail/E-posta: kennedy@bilkent.edu.tr

Submitted/Başvuru: 19.05.2020 Revision Requested/Revizyon Talebi: 20.10.2020

Last Revision Received/Son Revizyon: 21.10.2020

Accepted/Kabul: 13.12 .2020

\section{Citation/Atıf:}

Kennedy, Valerie. "Eastern Exoticism: Thackeray as Tourist and Anti-Tourist." Tarih Dergisi - Turkish Journal of History, 73 (2021): 131-148. https://doi.org/10.26650/iutd.739799

\section{ABSTRACT}

William Makepeace Thackeray's 1846 Notes on a Journey from Cornhill to Grand Cairo exemplifies the complexity of nineteenth-century travel-writing where exploration exists alongside tourism (and anti-tourism). In key Ottoman locations like Smyrna, Constantinople, and Cairo, the narrator's desire for Oriental exoticism is sometimes realised but often disappointed as the East becomes increasingly modernised and Westernised. These conflicting perspectives are expressed through allusions, East-West comparisons, and irony and satire in a self-conscious and unstable narrative.

Keywords: Orientalism, Imperialism, Progress, Tourism, Exoticism, Allusion

\section{öz}

William Makepeace Thackeray'in 1846 tarihli Notes on a Journey from Cornhill to Grand Cairo keşfin turizmle (ve turizm karşıtlığıyla) birlikte yer aldığı on dokuzuncu yüzyıl seyahat yazılarının karmaşıklığına örnek teşkil eder. İzmir, İstanbul, Kahire gibi Osmanlı şehirlerinde yazarın Doğu egzotizmi hevesi, Doğu'nun giderek modernleşmesi ve Batılılaşmasıyla ancak bazen gerçekleşmekte, fakat çoğu zaman hayal kırıklığıyla sonuçlanmaktadır. Bu çelişkili bakış açıları imalarla, Doğu-Batı karşılaştırmalarıyla, mahcup ve güvenilmez bir anlatı dâhilinde ironi ve taşlamayla aktarılır.

Anahtar sözcükler: Oryantalizm, emperyalizm, ilerleme, turizm, egzotizm, ima 


\section{Introduction}

The self-conscious instability of the narrative perspective of William Makepeace Thackeray's Notes on a Journey from Cornhill to Grand Cairo (1846) suggests its narrator's constantly varying attitudes. ${ }^{1}$ The tone is by turns naïvely enthusiastic, patriotic, protoimperialist, sceptical, and self-mocking. The narrative moves from the endorsement of Orientalist stereotypes of exoticism and sensuality to expressions of naïve wonder and delight when the traveller's textual expectations are confirmed or disillusionment when they are disappointed, along with sporadic vehement condemnations of Oriental violence and corruption. The text is also characterised by the dual presence of Thackeray as implied author and the persona of Michael Angelo Titmarsh (v-vi, 67), one of Thackeray's many pseudonyms, which he was later to use in his five 'Christmas Books' and in the 1850 satirical travelogue, The Knickleburys on the Rhine, and which, as Gordon Ray observes, 'by the middle 1840s', had become 'practically Thackeray's alter ego'.2 As J. Russell Perkin argues, Thackeray frequently ironises Titmarsh because of the unreliability of his Orientalist judgements, but the Orientalist perspective of Cornhill to Cairo cannot be uniquely identified with Titmarsh: ${ }^{3}$ it is also derived from Thackeray's memories of his youthful fondness for the Arabian Nights ${ }^{4}$ and qualified by the adult author's negative judgments of Oriental rulers and institutions. Thus in what follows I shall refer to 'the narrator' rather than distinguishing between Thackeray and Titmarsh. As the mention of 'Cornhill' in the travelogue's title indicates, the narrative persona is also characterised by Thackeray's knowing 'man-about-town' or 'man-of-the-world' pose, and by the perspective of the professional journalist who lives by his pen, both of which contribute to the self-consciousness and variability of the narration. ${ }^{5}$

In Cornhill to Grand Cairo the instability of Thackeray's perspective on some key sites in the Ottoman World - Smyrna (İzmir), Constantinople (İstanbul), and Cairo - is derived partly from his awareness that, on the one hand, readers of a travelogue on the Orient will expect exoticism, as he does, and, on the other, that such exoticism is hard to provide, given the ongoing modernisation of the East thanks to the influence of Western technology and the development of tourism. As Edward W. Said argues, for Europeans, the Orient was often as much an example of 'imaginative geography' as it was a real place, that is, a site for fantasies, fears, and desires of various kinds. ${ }^{6}$ Thackeray's journey on a $\mathrm{P}$ and $\mathrm{O}$ steamer also demonstrates the development

1 References to Thackeray's travelogue will be given parenthetically in the text, by page number.

2 Quoted in J. Russell Perkin 'Thackeray and Orientalism: Cornhill to Cairo and The Newcomes', English Studies in Canada, Vol. 16 No. 3 (September 1990), pp. 297-313, 299.

3 Perkin, ibid., p. 302.

4 Leonee Ormond, 'Cayenne and Cream Tarts: W. M. Thackeray and R L. Stevenson', in Arabian Nights in English Literature: Studies in the Reception of The Thousand and One Nights into British Culture, ed. Peter L. Caracciolo, Macmillan, London, 1988, pp. 178-196, pp. 178-180.

5 I am indebted to the comments of Tarih Dergisi's first reviewer for the observations in this sentence.

6 See Orientalism, Rouledge and Kegan Paul, London, 1978, p. 55. 
of tourism through technology. To use James Buzard's terminology, Thackeray may be seen as tourist and anti-tourist: travelling as part of the beginnings of tourism as a leisure industry, and yet at times differentiating himself from his fellow tourists, and aware of following in the footsteps of many earlier travellers. ${ }^{7}$ The desire for the exotic can be seen in the narrator's many allusions to the Arabian Nights and to the world of London theatre and popular entertainment, while the disillusionment at the lack of exoticism accompanied by a sense of belatedness emerges in the contrasts between London or English life and the East, and the modernisation of the Oriental world is the object of both irony and satire. ${ }^{8}$

\title{
Transient Exoticism: The Arabian Nights and Popular London Entertainment
}

The Arabian Nights and the world of London theatre or popular entertainment are key reference points in Cornhill to Grand Cairo, linking the narrator's memories of boyhood pleasure and excitement to adult escapism, and being used in the travelogue to evoke the exoticism of the Orient. Explaining the 'wonder' and the 'delightful shock' of first seeing Smyrna, the narrator says:

\begin{abstract}
Some men may read this who are in want of a sensation. If they love the odd and picturesque, if they loved the 'Arabian Nights' in their youth, let them book themselves on board one of the Peninsular and Oriental vessels, and try one dip into Constantinople or Smyrna. Walk into the bazaar, and the East is unveiled to you: how often and often have you tried to fancy this, lying out on a summer holiday at school! It is wonderful, too, how like it is: you may imagine that you have been in the place before, you seem to know it so well! (p. 82)
\end{abstract}

The passage exemplifies what Said calls 'the textual attitude' to the Orient, that is, the tendency to describe an unfamiliar place in relation to 'what one has read about it," in the words, 'how like it is' and 'you seem to know it so well!'. ${ }^{10}$ The description of Smyrna as a whole also reveals one side of the ambivalence of the Western traveller's reaction to the East, his 'shivers of delight in - or fear of - novelty', and his search for an alternative to European conventions and repression in the realm of sexual fantasy, ${ }^{11}$ here timidly suggested by the word, 'unveiled'.

7 See Buzard, The Beaten Track: European Tourism, Literature, and the Ways to 'Culture,' 1800-1918, Oxford University Press, Oxford, 1993, pp. 80-154; Buzard identifies faster modes of travel as one of the defining features of the transformation of individual travel into group tourism (pp. 35-36). Buzard's model of travel being replaced with tourism and anti-tourism, it should be said, is most apposite as a description of travel writing about Europe. Elsewhere, in Africa or the Middle East, the tropes of exploration and adventure continue to characterise many nineteenth- and early twentieth-century travel accounts.

8 Some of Thackeray's illustrations are also satirical, notably those of the 'negro holiday' in Alaxandria and the chief eunuch in Constantinople, which both offer stereotyped caricatures of Negro features (pp. 246, 247).

9 Ibid., p. 93; see also Perkin, ibid., pp. 299-300.

10 See Robert Hampson 'Thackeray as Travel-Writer', The Yearbook of English Studies, Vol. 34, (2004), pp. 214229, pp. 217, 221 for brief comments on Thackeray's intertextual references.

11 Said, ibid., pp. 59, 190. 
Thackeray's narrator then lists Smyrna's exotic sights for the first-time visitor, which are, by the nineteenth-century, conventional images of the Orient: 'real Turks', 'the town with minarets and cypresses, domes and castles; great guns ... firing off, and the blood-red flag of the Sultan flaring over the fort', 'woods and mountains [which] came down to the gulf's edge, and ... a score of pleasant episodes of Eastern life', as well as 'cottages with quaint roofs; silent cool kiosks, where the chief of the eunuchs brings down the ladies of the harem' ( $\mathrm{p}$. 82). He adds: 'I saw Hassan, the fisherman, getting his nets; and Ali Baba going off with his donkey to the great forest for wood' (p. 82). The references to Hassan and Ali Baba suggest the Arabian Nights, although the stories in the Nights contain no fisherman called Hassan; the fisherman in 'The Fisherman and the Jinni' is unnamed and the story, 'Ali Baba and the Forty Thieves', is in fact a folk tale added to the Nights by Antoine Galland. ${ }^{12}$ In Smyrna Thackeray admits that on later visits the magic may disappear, but nonetheless asserts that the first two hours 'are beyond measure delightful' (p. 83). However, sometimes even the Arabian Nights comparison loses its romance when faced with Oriental reality. In Alexandria 'among the natives, the stranger can't fail to remark (as the Caliph did of the Calenders in the "Arabian Nights") that so many of them have only one eye. It is the horrid ophthalmia which has played such frightful ravages with them' (p. 241). As Edward William Lane demonstrates, opthalmia was very common in mid-nineteenth-century Egypt, ${ }^{13}$ but Thackeray transforms what might be a neutral description into a negative Oriental stereotype: here the East is associated with disease: the exotic has become sinister.

The exoticism of the East is often expressed through comparisons to popular London theatre and entertainment. The first of these occurs in Smyrna, when the narrator first sees camels:

Whole strings of real camels, better even than in the procession of Blue Beard, with soft rolling eyes and bended necks, swaying from one side of the bazaar to the other to and fro, and treading gingerly with their great feet. O you fairy dreams of boyhood! O you sweet meditations of half-holidays, here you are realised for half-an-hour! (pp. 86-87)

Here again, the East is the world of boyhood 'fairy dreams', an unreal and exceedingly transient experience. The reference to the story of Blue Beard seems to be, not to the well known fairy-tale, but to Blue Beard; or, Female Curiosity by George Colman the Younger, ${ }^{14}$ which includes a camel carrying treasure in Bluebeard's train when he arrives to claim Fatima as his wife. Similarly, the extended allusion to the Theatre Royal, Drury Lane, is used to describe the magic of the first sight of Constantinople from the Golden Horn:

12 See 'The Thousand and One Nights'.

13 See his 1836 Manners and Customs of the Modern Egyptians (pp. 2, 3, 139, 236-237).

$146^{\text {th }}$ Edition, T. Collins, London, 1806 (1798). 
the fog cleared off as it were by flakes, and as you see gauze curtains lifted away, one by one, before a great fairy scene at the theatre. This will give idea enough of the fog; the difficulty is to describe the scene afterwards, which was in truth the great fairy scene, than which it is impossible to conceive anything more brilliant and magnificent. I can't go to any more romantic place than Drury Lane to draw my similes from-Drury Lane, such as we used to see it in our youth, when to our sight the grand last pictures of the melodrama or pantomime were as magnificent as any objects of nature we have seen with maturer eyes. Well, the view of Constantinople is as fine as any of Stanfield's best theatrical pictures, seen at the best period of youth, when fancy had all the bloom on her-when all the heroines who danced before the scene appeared as ravishing beauties, when there shone an unearthly splendour about Baker and Diddear - and the sound of the bugles and fiddles, and the cheerful clang of the cymbals, as the scene unrolled, and the gorgeous procession meandered triumphantly through it — caused a thrill of pleasure, and awakened an innocent fulness of sensual enjoyment that is only given to boys. (pp. 97-98)

As in Smyrna, the exotic location becomes a place for reliving the magic of childhood experiences and escaping from adult life. Thackeray represents the boys' and his own previous 'sensual enjoyment' as innocent, while the references to the 'theatrical pictures' of Clarkson Frederick Stanfield and the actors, Baker and Diddear, ${ }^{15}$ suggest both the childhood wonder at the 'brilliant and magnificent' city of Constantinople, and, as in Smyrna, the sense that the wonder is both fragile and transitory. This exoticising description is immediately followed by a self-conscious dissection of the assumptions on which it rests, but then, changing his perspective once more, the narrator immediately reasserts that 'The view of Constantinople resembles the ne plus ultra of a Stanfield diorama, with a glorious accompaniment of music, spangled houris, warriors, and winding processions, feasting the eyes and the soul with light, splendour, and harmony' (p. 98). Stanfield was from 1823 to 1834 the resident scene-painter at the Theatre Royal, and during that time he produced not just spectacular scenery but also moving dioramas, to which the narrator refers here. Again, Oriental exoticism is partly the result of its confirmation of a familiar (this time a visual) text, and of an earlier, boyhood, experience.

But the narrator then self-consciously comments on the possible ineffectiveness of such comparisons and the difficulty of creating the impression of the exotic: 'If you were never in this way during your youth ravished at the play-house, of course the whole comparison is useless ....' (pp. 98-99). He suggests other ways to communicate his first impression of the city. He first proposes combining the words, 'mosque, minaret, gold, cypress, water, blue, caïques, seventy-four, Galata, Tophana, Ramazan, Backallum,' ${ }^{16}$ but insists, 'your

15 The Tatler lists 'Mr Baker' as playing the Duke of Venice and 'Mr Diddear' as Bedamar in Thomas Otway's Venice Preserved. See Leigh Hunt, (ed.) The Tatler: A Daily Journal of Literature and the Stage, J. Onwhyn, London 1830, 1, p. 112.

16 The words, 'seventy-four,' refer to a Turkish warship, like that captained by the 'Captain Pasha,' the Grand Admiral of the Turkish fleet, which the travellers encounter off Beirut (p. 238); 'Backallum' is Thackeray's rendering of the Turkish 'bakalım,' meaning 'let us see' or 'we shall see'. 
imagination will never be able to depict a city out of them' (p. 99). Then he offers us measurements: 'suppose I say the Mosque of St. Sophia is four hundred and seventy-three feet in height, measuring from the middle nail of the gilt crescent surmounting the dome to the ring in the centre stone; the circle of the dome is one hundred and twenty-three feet in diameter, the windows ninety-seven in number' (p. 99). However, he immediately undercuts these 'facts,' stating wryly that 'all this may be true, for anything I know to the contrary,' but asking 'who is to get an idea of St. Sophia from dates, proper names, and calculations with a measuring-line? ... Has your fancy, which pooh-poohs a simile, faith enough to build a city with a foot-rule?' (p. 99).

The other significant allusion to popular entertainment used in relation to exoticism is that of Vauxhall Gardens, which by the early nineteenth century was famous for its illuminations and for its miscellaneous entertainments. It was also, less salubriously, known as a place for the activities of prostitutes and pickpockets. It is perhaps not so surprising then, that in Thackeray's travelogue the references to Vauxhall Gardens relate to the disappointment of the desire for exoticism, even though for some nineteenth-century visitors it still functioned as a symbol of excitement and adventure. Describing the Vauxhall Gardens entertainments, which took place at night, the Edinburgh Encyclopedia of 1830 compares the impression produced to be 'similar to that which is called up on reading some of the stories in the The Arabian Nights' ${ }^{17}$ Conversely, Thackeray uses the simile of places being like 'Vauxhall in the daytime' to suggest the disappearance of Eastern exoticism. In Constantinople, the different parts of the Seraglio 'have a romantic look in print; but not so in reality': 'Most of the marble is wood, almost all the gilding is faded, the guards are shabby, the foolish perspectives painted on the walls are half cracked off. The place looks like Vauxhall in the daytime' (p. 131). The simile also undermines any sexual promise suggested by the word, 'Seraglio'. He later calls the comparison 'a true and real one', and it reappears when he surveys the buildings which dramatise the 'double decay' of the Knights Hospitaller and 'the old Mahometanism' (pp. 140, 141) in Rhodes:

it is unseemly to see such a Grand Potentate in such a state of decay: the son of Bajazet
Ilderim insolvent; the descendants of the Prophet bullied by Calmucs and English and
whipper-snapper Frenchmen; the Fountain of Magnificence done up, and obliged to coin
pewter! Think of the poor dear houris in Paradise, how sad they must look as the arrivals
of the Faithful become less and less frequent every day. I can fancy the place beginning to
wear the fatal Vauxhall look of the Seraglio, and which has pursued me ever since I saw
it.... (p. 143)

With its multiple allusions and changing tone, the passage dramatizes the loss of the past romantic world of both the Christian Knights and the Muslims and laments the decline of the

17 'London', The Edinburgh Encyclopaedia (1832), Vol 12, p. 228. 
Ottoman Empire in the allusion to Beyazit I (r. 1389-1402), also known as Beyazit Yildırım (The Thunderbolt). ${ }^{18}$ The influence of Russia and Western European powers over the Ottoman rulers of the 1840s is evoked in the references to 'Calmucs and English and whipper-snapper Frenchmen,' 'Calmucs' presumably referring to Russian influence: the Kalmyks or Kalmucks were a Mongol people absorbed into the Russian empire in the course of the eighteenth century. Finally, the traveller imagines that even the Muslim paradise with the "poor dear houris', figures central to Romantic and Victorian Orientalist stereotyping of the East, is now as shabby and disappointing as the badly maintained Seraglio in Constantinople. The 'fatal Vauxhall look' functions as shorthand for the East as both the locus of the desire for escape from European mundaneness through exoticism and the disappointment of that desire.

\section{The Familiar in the Exotic: The Disillusioned Tourist}

Many of the comparisons or contrasts of the East with London or English life suggest the loss of romance in the English context and its continued existence in the East. Others are used to dramatise the loss of chivalry and romance more generally. Still others, like the 'Vauxhall in the daytime' simile, as we have seen, suggest disillusionment with the reality of the traveller's experience of the Orient (or southern Europe) as opposed to his romantic or exotic expectations.

Some comparisons of East and West assert the Orientalist trope of the romance of the East in contrast with prosaic nineteenth-century London. In Constantinople, the narrator declares: 'I can fancy the scene about the quays [along the Bosphorus] somewhat to resemble the river of London in olden times, before coal-smoke had darkened the whole city with soot', because now the 'wherry-boats' of London's past have been destroyed by 'bridges and steamers' (p. 101). In London, progress and industry destroy the picturesque, which still survives in Constantinople where 'the caïque is still in full perfection: there are thirty thousand boats of the kind plying between the cities; every boat is neat, and trimly carved and painted ... and with a purple sea for a background, every one of these dashing boats forms a brilliant and glittering picture' (p. 101). Perversely, though, Thackeray has earlier seen the 'smoke' of 'honest London' as contrasting with Lisbon's 'dust': the Orient in Constantinople retains its exoticism whereas southern Europe embodies neglect and inactivity (p. 131).

Other comparisons suggest that the loss of the romance of the past characterises both East and West, most strikingly on the island of Rhodes, once the headquarters of the Knights of St. John, and later a locus of Ottoman power in its heyday, where the narrator praises 'The chivalrous relics' as 'very superb' and 'a thousand times more picturesque' than modern fortifications (pp. 140, 141). He continues: 'Ancient war condescended to ornament itself,

18 Beyazit I is credited with creating the first centralised Ottoman state, extending the empire in both Europe and Anatolia, although he was later captured by Timur (Tamerlane) in 1402 and died in captivity. 
and built fine carved castles and vaulted gates: whereas, to judge from Gibraltar and Malta, nothing can be less romantic than the modern military architecture' (p. 141). He evokes the Turks 'who battered down chivalry,' the 'magnificent Pashas and Agas, who lived here in the intervals of war, and having conquered its best champions, despised Christendom and chivalry pretty much as an Englishman despises a Frenchman': they 'seem to be waiting their turn of destruction now', and he is 'strangely affected by witnessing the signs of this double decay' (p. 141). The narrator mourns the replacement of both 'Knighthood' and 'the old Mahometism' by petty commerce:

Now the famous house is let to a shabby merchant, who has his little beggarly shop in the bazaar; to a small officer, who ekes out his wretched pension by swindling, and who gets his pay in bad coin. Mahometanism pays in pewter now, in place of silver and gold. The lords of the world have run to seed. (p. 142)

However, contradictorily, this nostalgic declaration is immediately followed by the demand for 'a real account of those times and heroes - no good-humoured pageant, like those of the Scott romances - but a real authentic story to instruct and frighten honest people of the present day, and make them thankful that the grocer governs the world now in place of the baron?' (p. 143). Belatedness here takes the contradictory form of both a hankering for past romance and praise of the present unromantic but safer commercial world.

Earlier, at Smyrna, the narrator has expressed his preference for the commercial present rather than the violent past:

The paddle-wheel is the great conqueror. Wherever the captain cries 'Stop her!' Civilisation stops, and lands in the ship's boat, and makes a permanent acquaintance with the savages on shore. Whole hosts of crusaders have passed and died, and butchered here in vain. But to manufacture European iron into pikes and helmets was a waste of metal: in the shape of piston-rods and furnace-pokers it is irresistible; and I think an allegory might be made showing how much stronger commerce is than chivalry, and finishing with a grand image of Mahomet's crescent being extinguished in Fulton's boiler.

This I thought was the moral of the day's sights and adventures. (pp. 93-94)

The 'paddle-wheel', the 'piston-rods and furnace pokers', and 'Fulton's boiler' all function as symbols of modern industrial technology and progress. They represent 'civilisation' as opposed to 'the savages on shore', and the crusaders are represented as butchers, although it is hard to evaluate the degree of irony here. The narrator declares the victory of modern commerce over ancient romance to be 'irresistible', and seemingly applauds it in affirming the technological superiority of the West.

However, the West is not inevitably seen as superior. Travelling from Jaffa to Jerusalem, the narrator praises the three 'tall and exceedingly good-natured and mahogany-coloured 
infidel[s]' who, 'fasting through the Ramazan, and over as rough a road, for the greater part, as ever shook mortal bones, performed their fourteen hours' walk of near forty miles with the most admirable courage, alacrity, and good-humour' (p. 184). 'What a lesson of goodhumoured endurance it was to certain Pall Mall Sardanapaluses, who grumble if club sofa cushions are not soft enough!' the narrator exclaims (p. 185), evoking the legendary Assyrian king who 'exceeded all his predecessors in his sybaritic way of life', wore women's clothes and 'was responsible for the downfall of Assyria.' ${ }^{19}$ The Orientalist association of the East with female sexuality and therefore effeminacy ${ }^{20}$ is reversed to describe some of the upperclass young men in London, who embody the passivity and lack of virility conventionally associated with some 'Eastern' men; despite not being Christians, the 'mahogany-coloured infidels' are models of endurance and manliness. Similarly, Thackeray praises the Turks (the Muslims), in the Crusades because 'They seem to me the better Christians of the two", and he calls Saladin 'a pearl of refinement compared to the brutal beef-eating Richard' (pp. 142-143).

One of the most striking examples of the debunking of exoticist expectations occurs as the narrator approaches Egypt:

I had been preparing myself overnight, by the help of a cigar and a moonlight contemplation on deck, for sensations on landing in Egypt. I was ready to yield myself up with solemnity to the mystic grandeur of the scene of initiation. Pompey's Pillar must stand like a mountain, in a yellow plain, surrounded by a grove of obelisks as tall as palm-trees. Placid sphinxes brooding o'er the Nile - mighty Memnonian countenances calm - had revealed Egypt to me in a sonnet of Tennyson's, and I was ready to gaze on it with pyramidal wonder and hieroglyphic awe.

The landing quay at Alexandria is like the dockyard quay at Portsmouth: with a few score of brown faces scattered among the population. There are slop-sellers, dealers in marinestores, bottled-porter shops, seamen lolling about; flys [sic] and cabs are plying for hire; and a yelling chorus of donkey-boys, shrieking, 'Ride, sir! —Donkey, sir! —I say, sir!' in excellent English, dispel all romantic notions. The placid sphinxes brooding o'er the Nile disappeared with that shriek of the donkey-boys. You might be as well impressed with Wapping as with your first step on Egyptian soil. (pp. 239-240)

The narrator desires the exotic, but is disappointed. He declares his readiness to experience 'the mystic grandeur' of Egypt with 'solemnity', but his preparation for the experience is bathetic, with the tourist cliché of the cigar on the moonlit deck of the steamer. He imagines Pompey's Pillar by evoking 'obelisks as tall as palm-trees', but later he realises that 'Pompey's Pillar is by no means so big as the Charing Cross trophy' (p. 245). ${ }^{21}$ He quotes from Tennyson's

19 'Sardanapalus,' Encyclopedia Britannica.

20 See Said, ibid., pp. 6, 206-207.

21 See also Hampson, ibid., p. 226. It is not clear what the 'Charing Cross trophy' is, since the monument now in Charing Cross, a replica of the thirteenth-century monument to Queen Eleanor, was destroyed in 1647 and not rebuilt until 1865 . 
'A Fragment', which mourns the loss of the heroic days of the Pharaohs. Tennyson's speaker asks: 'but where, / Mysterious Egypt, are thine obelisks / Graven with gorgeous emblems undiscerned? / Thy placid Sphinxes brooding o'er the Nile? / Thy shadowing Idols in their solitudes, / Awful Memnonian countenances calm / Looking athwart the burning flats', ${ }^{22}$ and Thackeray's allusion conjures up the mystery of Egypt's Pharaonic past. Even here, however, the mystique is shattered by the sense of burlesque in the incongruous semantics when the narrator declares his readiness to feel 'pyramidal wonder and hieroglyphic awe'. Thackeray's text both exploits and undermines or mocks not only the 'textual attitude' to the Orient, but also the Orientalist tendency to see power only in the 'glorious past' of the East, compared with the 'backwardness' of the present. ${ }^{23}$ Once at Alexandria, the narrator's disillusionment intensifies because of the similarity to an English dockyard scene and the presence of the English-speaking donkey-boys. Alexandria is no more exotic than Wapping, a poor dockland area in the East End of London associated with violence, notably the Ratcliff Highway murders of 1811.

When the narrator first sees the Pyramids from afar, the disillusionment continues. He asks: 'Are we so blases [sic] of the world that the greatest marvels in it do not succeed in moving us?' (p. 253) and continues: 'My sensation with regard to the Pyramids was, that I had seen them before: then came a feeling of shame that the view of them should awaken no respect'; he looks at his fellow travellers, and concludes: 'the truth is, nobody was seriously moved ... And why should they, because of an exaggeration of bricks ever so enormous? I confess, for my part, that the Pyramids are very big' (p. 253). The deflationary note is struck again definitively when Thackeray actually travels to see the Pyramids. 'There is nothing sublime about it' (p. 297), says the narrator, because the visit to the Pyramids has degenerated into the typical tourist experience of being pestered by unwanted guides and attendants wanting money. ${ }^{24} \mathrm{He}$ imagines his reader's reproaches and replies to them:

- And this is all you have to tell about the Pyramids? Oh! for shame! Not a compliment to their age and size? Not a big phrase, — not a rapture? Do you mean to say that you had no feeling of respect and awe? Try, man, and build up a monument of words as lofty as they are - they, whom 'imber edax' and 'aquilo impotens' and the flight of ages have not been able to destroy.

- No: be that work for great geniuses, great painters, great poets! This quill was never made to take such flights; it comes of the wing of a humble domestic bird, who walks a common; who talks a great deal (and hisses sometimes); who can't fly far or high, and drops always very quickly; and whose unromantic end is, to be laid on a Michaelmas or Christmas table, and there to be discussed for half-an-hour — let us hope, with some relish. (pp. 298-299)

22 Tennyson, 'A Fragment' (1831). The Suppressed Poems of Alfred, Lord Tennyson, 11. 11-17.

23 See Said, ibid, pp. 56, 204-205.

24 A similarly deflationary mode (along with fulsome praise of Punch), occurs in Thackeray's two-part article, 'Punch at the Pyramids', submitted to Punch under the pseudonym of 'The Fat Contributor' (1 and 8 February 1845), pp. 61, 75. For this aspect of the anti-tourism complaint see Buzard, ibid., pp. 122-24. 
The implied reader here is a classically-educated man who quotes snippets of Horace's Ode (3.30.3-4), suggesting that 'neither greedy fire nor the powerless North Wind could destroy' the Pyramids, ${ }^{25}$ but, having demonstrated his own classical education through the untranslated allusion, Thackeray's narrator immediately undermines his scholarly pose by identifying his pen as a goose quill, ending with an incongruous and facetious reference to the cooked goose at an English Christmas dinner. The exotic is replaced by the comfort of the mundane.

\section{Satirising Modernity in the East in Cornhill to Grand Cairo}

The modernisation or Westernisation of the Orient is frequently ironised or satirised in Cornhill to Grand Cairo. The narrator mocks Byronism and satirises Oriental brutality and corruption and both welcomes and laments the seemingly inevitable changes in Eastern societies brought about by Western influence.

By the 1840s, one of the conventions of Eastern travel was Byronism. Not only had George Gordon, Lord Byron, himself travelled in Greece and other parts of the Ottoman empire and written many poems with Eastern contexts and characters, but by the late 1830s and 1840s he and his work had become part of the tourist's standard equipment by being selectively quoted in Murray's Handbooks, although as Buzard says, 'Murray's Byron, like Disraeli's, is void of political content. ${ }^{26}$ Thackeray's narrator, finding the women of Athens disappointingly unattractive, dismisses as 'cant' Byron's depictions of 'those superb, tawdry, unwholesome exotics, which are only good to make poems about' (p. 75). He continues:

That man never wrote from his heart. He got up rapture and enthusiasm with an eye to the public; but this is dangerous ground, even more dangerous than to look Athens full in the face, and say that your eyes are not dazzled by its beauty. The Great Public admires Greece and Byron: the public knows best. 'Murray's 'Guide-book' calls the latter 'our native bard.' Our native bard! Mon Dieu! HE Shakespeare's, Milton's, Keats's, Scott's native bard! Well, woe be to the man who denies the public gods! (pp. 75-76) ${ }^{27}$

Thackeray's narrator knowingly risks alienating Byron enthusiasts by rejecting their enthusiasm for both Hellenism and Byronism. ${ }^{28} \mathrm{He}$ begins the chapter on Athens by explaining that his lack of enthusiasm for the city is 'the inestimable benefit of a ten years' classical education,' which in fact meant that he suffered 'ten years' banishment of infernal misery, tyranny, annoyance; giving over the fresh feelings of the heart of the little Michael Angelo (Titmarsh) to the discipline of vulgar bullies, who ... lead tender young children

25 The quotation is from Odes 3.30.3-4 where the poet seeks to build a lasting poetic monument; the Latin reads: 'Quod non imber edax, non Aquilo impotens / Possit diruere.'

26 See Buzard, ibid., pp. 121, 124.

27 See also Buzard, ibid, pp. 115-116 for comments on Byron's influence.

28 See Hampson, ibid., p. 216. 
to the Temple of Learning ... with clenched fists and low abuse' (p. 67). ${ }^{29}$ In relation to Byron, the narrator's horror at the idea of the poet as " "the public bard" is expressed with the adornment of not one but four exclamation marks and the comic affectation of the French, 'Mon Dieu!'30

A later reference to Byron functions somewhat differently, being used to underline the disappearance of the romance of exoticism and difference in the contemporary Orient. In Smyrna, wishing that painters would create 'familiar views of the East: not processions, grand sultans, or magnificent landscapes; but faithful transcripts of everyday Oriental life', the narrator gives a series of examples, like the camels: 'couched in the market-places, lying by thousands in the camel-square, snorting and bubbling after their manner, the sun blazing down on their backs, their slaves and keepers lying behind them in the shade' (p. 91). He continues:

These are very humble incidents of travel. Wherever the steamboat touches the shore adventure retreats into the interior, and what is called romance vanishes. It won't bear the vulgar gaze; or rather the light of common day puts it out, and it is only in the dark that it shines at all. There is no cursing and insulting of Giaours now. If a Cockney looks or behaves in a particularly ridiculous way, the little Turks come out and laugh at him. A Londoner is no longer a spittoon for true believers: and now that dark Hassan sits in his divan and drinks champagne, and Selim has a French watch, and Zuleika perhaps takes Morison's pills, Byronism becomes absurd instead of sublime, and is only a foolish expression of Cockney wonder. (p. 93)

Readers recall Byron because of the reference to 'Giaours' (non-Muslims), The Giaour (1813) being the first of Byron's five very popular exotic Turkish Tales. For Thackeray's narrator the romance of the East has been lost because of the pressure of tourism and progress (represented again by the steamboat) and European trade with the East in the form of the 'champagne', the 'French watch', and 'Morrison's pills'. But here it is conceded, albeit in passing, that 'Byronism' was once 'sublime', even if it now 'absurd' and 'only a foolish expression of Cockney wonder' ${ }^{31}$ As Robert Hampson argues, Thackeray sees that 'commerce has triumphed where crusaders and chivalry failed. More subtly, as a result, an

29 Here Titmarsh and Thackeray are indistinguishable: Thackeray's unhappiness at public school is well known. See 'William Makepeace Thackeray, Encyclopedia Britannica. Kinglake reveals a similar disenchantment with public school classical education in relation to Homer, although his pre-school boyish enthusiasm survived: see Eothen, Oxford University Press, Oxford 1982 (1844) pp. 42-45.

30 'Mon Dieu!' also occurs in a comic moment of mock-suspense in the hammam in Constantinople when the narrator's dragoman leaves him, dressed only in 'three large cotton napkins, with a white turban round [his] head,' to the attentions of the Turkish masseur: "'Mon Dieu! what was going to happen?"' the narrator wonders (pp. 105-106).

31 Thackeray sometimes uses 'Cockney' disparagingly, as here, but sometimes to refer neutrally to all the travellers, including himself (p. 83). See $O E D$, “Cockney”, 4.a. 
earlier mode of exoticizing and essentializing is registered as out-dated'. ${ }^{32}$ Thus the critical narrative perspective on Byron both appeals to and undermines the value ascribed to Oriental exoticism; it might also be seen to be somewhat ironic, given the importance of the theatrical allusions in Thackeray's travelogue, because, in Buzard's words, it was 'the much-noted histrionic, theatrical tenor of Byron's public persona' which made Byron central 'to the purposes and attitudes of nineteenth-century tourism'; as he says, 'Byron helped to turn the Continent into a great theatre for travellers' acts of cultural self-dramatization'. ${ }^{33}$ Moreover, when on the way to the Pyramids, Thackeray's narrator deplores seeing that 'at the gate of one country-house ... the Bey's GIG was in waiting, - a most unromantic chariot' (p. 420), he takes up a position somewhat similar to Byron's in the latter's sardonic comment on some Englishwomen in the Alps. Byron remembered, 'at Chamouni, in the very eyes of Mont Blanc, hearing [an English] woman [...] exclaim to her party, "Did you ever see any thing more rural?" as if it was Highgate, or Hampstead, or Brompton, or Hayes, — "Rural!" quotha. Rocks, pines, torrents, glaciers, clouds, and summits of eternal snows far above them — and "rural!" 34 If Byron deplores the domestication of the Romantic scenery of the Alps by London tourists, Thackeray, a London tourist himself, mourns the loss of exoticism and romance of the East.

When Thackeray considers the arbitrary power of Ottoman rule in Constantinople and Cairo, satire becomes savage critique. In Cairo the narrator declares: 'The much-maligned Orient, I am confident, has not been maligned near enough', because 'none of us can tell the amount of horrible sensuality practised there' (p. 265), although the examples that follows relate to violence rather than sensuality. This may be because, as Norman Daniel says, violence, lasciviousness, and deceit were long-lasting and interconnected Orientalist stereotypes of the East and of Islam. ${ }^{35}$ In Constantinople, criticising the "fashion of our travellers to apologize for Turkish life, of late, and paint glowing, agreeable pictures of many of its institutions', Thackeray finds 'a good subject for a Ghazul, in the true new Oriental manner' in the mausoleum 'of the late Sultan Mahmoud's family', in contemplating 'the tombs of Mahmoud's grandsons, nephews of the present Light of the Universe, and children of his sister, the wife of Halil Pacha [sic]' (pp. 116-117, 117, 118). ${ }^{36}$ As the narrator explains, the first grandson was assassinated on the orders of Sultan Mahmud II (r. 1808-1839), the second on the orders of Abdulmecid (r. 1839-1861). Thackeray then summarises an imagined three-act tragic poem based on these events, showing the anguished mother's reactions to the

32 Hampson, ibid., p. 224.

33 Ibid., pp. 116, 117

34 Quoted in Buzard, ibid., p. 92.

35 See Norman Daniel, Islam Europe and Empire, Edinburgh UP., Edinburgh 1966, p. 6,

36 Thackeray misuses the word, ghazal: the $O E D$ defines it as 'A species of Oriental lyric poetry, generally of an erotic nature, distinguished from other forms of Eastern verse by having a limited number of stanzas and by the recurrence of the same rhyme'. 
murder of the first son at the age of six weeks, then the birth of the second and the mother's hopes it will be allowed to live, and finally her agony at the death of the second, her cursing of the Sultan, and her own death. He concludes:

After the murder of that little child, it seems to me one can never look with anything but horror upon the butcherly Herod who ordered it. The death of the seventy thousand Janissaries ascends to historic dignity, and takes rank as war. But a great Prince and Light of the Universe, who procures abortions and throttles little babies, dwindles away into such a frightful insignificance of crime, that those may respect him who will .... To do the Turks justice - and two days' walk in Constantinople will settle this fact as well as a year's residence in the city - the people do not seem in the least animated by this Herodian spirit.' (p. 120)

The imaginary poem dramatizes the brutality of Ottoman power through the heavily ironic, repeated references to the Sultan as 'the Light of the Universe', ${ }^{37}$ the Biblical allusion to 'the butcherly Herod', ${ }^{38}$ and the distinction between Turkish institutions and rulers and 'the people' who 'do not seem in the least animated by this Herodian spirit': the next paragraph goes on to give several examples of ordinary people's kindness to children.

In Cairo the narrator offers a series of anecdotes to justify his hyperbolic claim that 'The life of the East is a life of brutes' (p. 265). The first concerns the execution of an 'Arnaoot', an Albanian soldier, which escalates into other examples of bloodthirstiness: a married woman, witnessing the execution, smears herself with the blood as a remedy for barrenness, whereupon, the narrator tells us, another Albanian says "WWhat, you like blood, do you?" (or words to that effect). "Let's see how yours mixes with my comrade's", and shoots her, only to be immediately arrested and, no doubt, says the narrator, 'to-morrow morning will have HIS head off too. It would be a good chapter to write - the Death of the Arnaoot - but I shan't go. Seeing one man hanged is quite enough in the course of a life. J'y ai ete [sic], as the Frenchman said of hunting' (p. 267). The assumed flippancy of the final two sentences does not disguise the narrator's disgust at both the superstition and the mindless violence which are represented as typical of Egyptian women and Albanian soldiers respectively. This anecdote is followed by that of the young Pasha, one of 'His Highness's grandsons', whom the narrator ironically baptises 'Bluebeard Pasha' 'lest a revelation of the name of the said Pasha might interrupt our good relations with his country', to show that this 'sort of pistol practice is common enough here ... and not among the Arnaoots merely, but the higher orders' (p. 268). The young Pasha, who is being tutored in 'the usages of polite society' by a Cambridge scholar, 'Mr. Mac Whirter, B.A.', is walking with him when their talk is interrupted by a fellah begging the Pasha for justice; the Pasha dismisses him, and

37 Elsewhere the epithets 'the Zilullah' (the shadow of God) and 'the Refuge of the World' are also used satirically in relation to Sultan Abdulmecid (pp. 178, 177).

38 Matthew 2: 16. 
then, when the fellah repeats his petition, shoots him dead. The tutor remonstrates, comically and obsequiously telling his charge that "we do not shoot an undergraduate at Cambridge even for walking over a college grass-plot"” and that "this method of ridding yourself of a poor devil's importunities, is such as we should consider abrupt and almost cruel in Europe" (p. 270). This has the effect only of making the Pasha threaten the tutor himself with execution. The third 'facetious anecdote' about Egypt, as the narrator calls it, relates to the corruption of the taxation system (p. 270). He first explains, with some self-interest, that he cannot divulge the identity of his source for the second and third anecdotes, who is 'a well-informed gentleman residing at Cairo,' because Cornhill to Grand Cairo will be found in the circulating libraries there (p. 270). Then he offers a long introduction explaining that in Egypt some farmers act as middlemen between the treasury and the peasants, which 'involves an intolerable deal of tyranny and extortion on the part of those engaged to levy the taxes, and creates a corresponding duplicity among the fellahs, who are not only wretchedly poor among themselves, but whose object is to appear still more poor, and guard their money from their rapacious overseers' (pp. 270-271). He comments:

Thus the Orient is much maligned; but everybody cheats there: that is a melancholy fact. The Pasha robs and cheats the merchants; knows that the overseer robs him, and bides his time, until he makes him disgorge by the application of the tremendous bastinado; the overseer robs and squeezes the labourer; and the poverty-stricken devil cheats and robs in return; and so the government moves in a happy cycle of roguery. (p. 271) ${ }^{39}$

After this lengthy exordium, he tells the story: the Pasha ${ }^{40}$ takes pity on the peasants of one exceedingly poor village, 'El Muddee', and forbids his intermediary, 'Skinflint Beg', to bastinado them any further, but the intermediary assures the Pasha that the villagers are hiding their wealth. He tricks them into bringing the five hundred purses they owe in tax to the Pasha by pretending that this will be their contribution (along with his) for the use of some very fertile land. They agree: the Sultan collects his tax, the peasants lose their money and are bastinadoed, and Skinflint Beg is promoted to 'Skinflint Bey' (pp. 271-275), with the narrator concluding cynically that the system 'may be studied with admiration' in Ireland or 'Derrynane beg' (p. 275), ${ }^{41}$ the names adding a farcical element to the satire.

The loss of Oriental romance and exoticism is both lamented and ironised in Cornhill to Grand Cairo. As we have seen, at the Pyramids, Horace is quoted to emphasise the narrator's

39 Grosrichard quotes Tournefort on the same pattern in Constantinople in 1717; Tournefort sees the Ottoman hierarchy as a pyramid of "'bloodsucker[s]"; this continues, as Grosrichard says, "all the way along the chain to its very end,' where 'there is only the populace that is endlessly subject to tithes and taxes'. See The Sultan's Court: European Fantasies of the East, trans. Liz Heron, Verso, London and New York 1998 (1979), pp. 74-75.

40 The Pasha was Muhammad Ali, also known as Mehmed Ali (r. 1805-1848).

41 This is one of several derogatory references to Ireland: see pp. 8, 72, 74. Thackeray represents both the Irısh and the Jewish peoples through caricatured negative stereotypes. This distressing aspect of the text has not been analysed in any detail here because it is not germane to his representation of Ottoman locations. 
disillusionment (pp. 298-99). The sensation of belatedness is also both used and mocked. At the end of the 'Constantinople' chapter, belatedness is combined with the motif of the loss of romance in the modern Orient:

I don't think I have anything more to say about the city, which has not been much better told by graver travellers. I with them, could see (perhaps it was the preaching of the politicians that warned me of the fact) that we are looking on at the last days of an empire; and heard many stories of weakness, disorder, and oppression. I even saw a Turkish lady drive up to Sultan Achmet's mosque in a Brougham. Is not that a subject to moralize upon? And might one not draw endless conclusions from it, that the knell of the Turkish dominion is rung; that the European spirit and institutions once admitted can never be rooted out again; and that the scepticism prevalent amongst the higher orders must descend ere very long to the lower; and the cry of the Muezim [sic] from the mosque become a mere ceremony? (p. 132)

Thackeray admits his belatedness: he has nothing else to say that has not been 'much better told by graver travellers'. Then his statement that he, his fellow travellers, and his readers, are looking on 'the last days of an empire' is mocked in the parenthetical clause 'perhaps it was the preaching of the politicians that warned me of the fact'. The lady in the brougham who drives up to 'Sultan Achmet's mosque' induces the narrator to 'moralise,' and the moral he draws in the three parallel 'that' clauses starts with his version of John Donne's bell tolling to mark a death, here the death of the Ottoman empire, and then moves to the ineluctable domination of that empire by 'the European spirit and institutions', and finally to the end of its religion of Islam. This final prediction, of course, now reads ironically in a way which its author could never have foreseen. The chapter on Constantinople ends with the narrator's justification of having written at all, after he has confessed his belatedness and admitted that he stayed there only 'eight days ... and knew not a syllable of the language' (p. 132). The second of these statements is not entirely true, as his earlier use of 'Backalam' ('Bakalım' ('We shall see') and 'Yang en Var' ('Yangin var!' 'Fire!') shows (pp. 99, 110), although the shortness of his stay underlines his status as a tourist.

\section{Conclusion}

If Cornhill to Grand Cairo can be seen to contribute to what V. G. Kiernan calls Europe's "collective day-dream of the Orient" 42 in terms of its deployment of the tropes of Eastern exoticism and romance, it also demonstrates that by 1846 the day-dream was hard to believe in and that the romance and exoticism were hard to find. They are disappearing as the Orient is modernised and Westernised, and images of the exotic are undermined further by the narrator's evocations of violence and corruption as Thackeray's boyhood memories of the Arabian Nights and the world of London theatre and popular entertainment come face to face with stories about the contemporary realities of life in the Ottoman Empire. In contrast to

42 Quoted in Said, ibid., p. 52. 
Alexander Kinglake's Eothen, published just two years earlier, Thackeray's text represents the transmutation of the traveller into the tourist. Like Eothen, Thackeray's text reveals the grand tour changing and extending eastwards after the end of the Napoleonic Wars, but Thackeray travels by that emblem of Victorian modernity, the steamer, unlike Kinglake who travels on horseback and by camel. If Thackeray's mockery of Byronism looks back to the conventions of Romantic travel and travel writing, the self-conscious, ironic, and satirical aspects of his travelogue anticipate and emphasise the sense of belatedness which will grow ever stronger as the nineteenth century continues, as Ali Behdad has shown in Belated Travelers. Thus, in terms of the development of travel writing, From Cornhill to Grand Cairo may be seen as a transitional work, while its 'urban and unheroic' narrator is typical of its author's mature oeuvre in his novels. ${ }^{43}$

Peer-review: Externally peer-reviewed.

Conflict of Interest: The author has no conflict of interest to declare.

Grant Support: The author declared that this study has received no financial support.

Hakem Değerlendirmesi: Dış bağımsız.

Çıkar Çatışması: Yazar çıkar çatışması bildirmemiştir.

Finansal Destek: Yazar bu çalışma için finansal destek almadığını beyan etmiştir.

\section{References/Kaynakça}

Behdad, Ali. Belated Travelers: Orientalism in the Age of Colonial Dissolution. Duke University Press, Durham, 1994.

Buzard, James. The Beaten Track: European Tourism, Literature, and the Ways to 'Culture', 1800-1918. Oxford University Press, Oxford, 1993.

Colman, George, the Younger. Blue Beard; or, Female Curiosity, $6^{\text {th }}$ Edition, T. Collins, London, 1806 (1798). https://www.goodreads.com/book/show/10062016-blue-beard-or-female-curiosity. Last accessed 18 May 2020.

Daniel, Norman. Islam Europe and Empire. Edinburgh University Press, Edinburgh, 1966.

'ghazal'. Oxford English Dictionary. https://www-oed-com.nls.idm.oclc.org/view/Entry/78044?redirected From=ghazal\#eid. Last accessed 21 April 2020.

Grosrichard, Alain. The Sultan's Court: European Fantasies of the East, trans. Liz Heron. Verso, London and New York, 1998 (1979).

Hampson, Robert. 'Thackeray as Travel-Writer', The Yearbook of English Studies, Vol. 34, (2004), pp. 214229.

Horace. Odes.

43 Hampson, ibid., 214. 
Hunt, Leigh, ed. The Tatler: A Daily Journal of Literature and the Stage, J. Onwhyn, London, 1830. Vol. 1, 112. https:// books.google.co.uk/books?id=YioTAAAAQAAJ\&pg=PA112\&lpg=PA112\&dq=Baker+and+Diddear\&sour ce=bl\&ots=EUr3k4ylC3\&sig=ACfU3U0GtZtt8Wf6gQV93TWQ-KOVocTkLw\&hl=en\&sa=X\&ved=2ahUKEwijwb7-nrDoAhWJgVwKHZBVCOkQ6AEwAnoECAYQAQ\#v=onepage\&q=Baker\%20and $\% 20$ Diddear\&f=false. Last accessed 21 April 2020.

Kinglake, Eothen: or Traces of Travel, Brought Home from the East. Oxford University Press, Oxford, 1982 (1844).

Lane, William Edward. Manners and Customs of the Modern Egyptians. London, 1836. https://scholarship. rice.edu/jsp/xml/1911/9176/71/lanma1890.tei-timea.html\#top. Last accessed 04 April 2020.

'London,' The Edinburgh Encyclopaedia (1832), Vol 12, p. 228. https://books.google.co.uk/books?id= PttEAQAAMAAJ\&pg=PA228\&lpg=PA228\&dq=\%E2\%80\%98splendidly+illuminated + at + night $+\ldots+$ with + about $+15,000+$ glass + lamps $\%$ E2\%80\%99\&source=bl\&ots=huXfoQD4Ss\&sig=ACfU3U2MU nAwnMCdDFkCfUamJLnBQ7_LGA\&hl=en\&sa=X\&ved=2ahUKEwjHt8nBo_noAhWZQUEAHWSc AOMQ6AEwDHoECAcQAQ\#v= onepage\&q=\%E2\%80\%98splendidly $\% 20$ illuminated $\% 20$ at $\% 20$ night $\% 20 \ldots \% 20$ with $\% 20$ about $\% 2015 \% 2$ C000\%20glass $\% 201$ amps $\%$ E2\%80\%99\&f=false. Last accessed 21 April 2020.

Ormond, Leonee. 'Cayenne and Cream Tarts: W. M. Thackeray and R L. Stevenson,' in Peter L. Caracciolo, (ed.) Arabian Nights in English Literature: Studies in the Reception of The Thousand and One Nights into British Culture. Macmillan, London, 1988, pp. 178-96.

Perkin, J. Russell. 'Thackeray and Orientalism: Cornhill to Cairo and The Newcomes' English Studies in Canada, 16: 3 (September 1990): pp. 297-313.

Said, Edward W. Orientalism. Routledge and Kegan Paul, London, 1978.

'Sardanapalus.' Encyclopedia Britannica. https://www.britannica.com/topic/Sardanapalus-legendary-kingof-Assyria. Last accessed 21 April 2020.

Tennyson, Alfred. 'A Fragment' (1831). The Suppressed Poems of Alfred, Lord Tennyson. https://archive. org/stream/suppressedpoemso00tennrich/suppressedpoemso00tennrich_djvu.txt. Last accessed 21 April 2020.

Thackeray, William Makepeace. Notes on a Journey from Cornhill to Grand Cairo.

https://ia802701.us.archive.org/33/items/notesajourneyfr00thacgoog/notesajourneyfr00thacgoog.pdf. Last accessed May 2, 2020.

Thackeray, William Makepeace. ('The Fat Contributor'), 'Punch at the Pyramids." Punch Vols. 8-9 (1 and 8 Feb. 1845), pp. 61, 75. https://books.google.co.uk/books?id=HnRHtOyMi24C\&pg=PA61\&lpg=PA61 \&dq $=\%$ E2\%80\%98Punch + at + the + Pyramids $\% 27 \&$ source=bl\&ots=KOSf9m835U\&sig=ACfU3U1ONUVm Iznzm_ALwR9AMd5-4ZVPA\&hl=en\&sa=X\&ved=2ahUKEwiP6rfxqPnoAhVGi1wKHSNhBPIQ 6AEwDnoECAkQAQ\#v=onepage \&q=\%E2\%80\%98Punch $\% 20 \mathrm{at} \% 20$ the $\% 20$ Pyramids' $\& \mathrm{f}=$ false.

The Thousand and One Nights.

https://heritage.bnf.fr/bibliothequesorient/en/thousand-and-one-nights-art. Last accessed 21 April 2020.

'William Makepeace Thackeray.' Encyclopedia Britannica. https://www.britannica.com/biography/WilliamMakepeace-Thackeray. Last accessed 21 April 2020. 